\title{
Protein to Osmolality Ratio Measurement
}

National Cancer Institute

\section{Source}

National Cancer Institute. Protein to Osmolality Ratio Measurement. NCI Thesaurus.

Code C92240.

The determination of the ratio of total protein compared to the osmolality a sample. The measurement may be expressed as a ratio or percentage. 